\title{
LA PRENSA FILIPINA EN ESPAÑOL ENTRE DOS GUERRAS (1899-1941)
}

DOI: http://dx.doi.org/10.12795/RiHC.2015.i04.02

\author{
Antonio Checa Godoy \\ Universidad de Sevilla \\ acheca@us.es
}

Recibido: 15-4-15

Aceptado: 18-5-15

Resumen: La derrota española en la guerra con Estados Unidos en 1898 no supone la extinción de la prensa en español en Filipinas. Aunque 1899 abre una nueva y muy distinta etapa en las islas, el español sigue siendo idioma oficial y en español se editarán múltiples periódicos de muy distintas orientaciones, incluida una prensa nacionalista contraria a la ocupación norteamericana y desde luego la prensa católica. Pero la introducción del inglés en la escuela, desplazando al español, supone que al cabo de dos generaciones se produzca una inversión de la situación, pasando el español, que ha sido también el idioma mayoritario en la literatura filipina, a un papel crecientemente secundario. En ese panorama, cuando también la prensa en idiomas locales se expande y se multiplican los periódicos bilingües o trilingües, la invasión de las islas por Japón en 1941 crea una nueva situación de la que el gran perjudicado será el periodismo en español. Este artículo describe y analiza todo ese proceso.

Palabras clave: Prensa, Filipinas, español, nacionalismo 
Abstract: The Spanish defeat in the war against United States in 1898 does not mean the extinction of the press written in Spanish in the Philippines. Although 1899 opens a new and very different stage in the islands, Spanish remains as the official language and multiple newspapers from many different backgrounds will be published, including a nationalist press opposed to the US occupation, and of course the Catholic press. But the introduction of English in school, forcing aside Spanish, will cause a reversal of the situation after mere two generations, leading Spanish, who has also been the main language of Philippine literature, to an increasingly supporting role. In this scenario, when the press written into local language also expands and bilingual or trilingual newspaper multiply, the invasion of the islands by Japan in 1941 stirs up a new situation where the journalism in Spanish language will be further harmed. This article describes the entire process.

Keywords: Newspapers, Philippines, spanish, nationalism

\section{Introducción}

El mantenimiento de una nutrida prensa en lengua castellana en Filipinas tras la guerra hispano-norteamericana y la sustitución de la administración española por la norteamericana, es una página poco conocida y poco apreciada del periodismo en español. Entre esa guerra y la invasión de las islas por Japón al final de 1941, que supone un nuevo terremoto para la comunicación y abre una etapa histórica diferente, se editan en Filipinas por encima de los 220 títulos en español, de ellos más de 30 diarios, con una rica prensa regional, además de un número cercano de títulos redactados en dos o incluso tres idiomas, con el español entre ellos. Ese amplio número de cabeceras responde a muy distintos objetivos, desde las que sencillamente buscan defender a la colonia y los intereses españoles, a las que utilizan el español como lengua vehicular en un archipiélago donde bullen una decena de idiomas relevantes, y a través de esa prensa reivindican la personalidad del pueblo filipino, sin olvidar periódicos obreros y religiosos, revistas culturales, científicas o recreativas en un abanico generoso.

Aunque raramente esas cabeceras, salvo algunos diarios, alcanzan amplia difusión, muchas llegan a ser influyentes, redactadas en su mayoría por varias generaciones de filipinos a los que las circunstancias llevan a ser a un tiempo periodistas, políticos y escritores. Jóvenes periodistas que elevan la literatura en lengua española a un nivel muy superior al alcanzado en el XIX, durante la colonia, y que además fundan partidos políticos u ocupan destacados puestos en instituciones oficiales, de la Biblioteca Nacional al Tribunal Supremo, pasando por las dos cámaras del parlamento.

Poco conocida, salvo algunos aspectos superficiales o muy concretos, nos proponemos en este artículo rescatar del olvido esa prensa y analizar sus rasgos básicos y su 
evolución. Queda, para otra investigación, el análisis de lo ocurrido en las islas desde la II Guerra Mundial a nuestros días.

\section{Fuentes disponibles}

Las fuentes primarias disponibles en España sobre la prensa en lengua española publicada en Filipinas tras 1898 son escasas, en contraste con la etapa colonial precedente. Entre la Biblioteca Nacional de España y la Hemeroteca Municipal de Madrid se localizan ejemplares -raramente colecciones amplias- de 26 publicaciones en español aparecidas en las islas desde 1899, un número muy insuficiente, y son aún más escasos en otras hemerotecas. Por fortuna, los procesos de digitalización emprendidos en Filipinas y Estados Unidos, incluso por empresas como Google, aunque más orientados a ofertar periódicos en inglés o tagalo y otros idiomas de Filipinas, incluyen también publicaciones bilingües y algunas más en español.

Por otro lado, no faltan publicaciones estadísticas con estimable rigor, como los Anuarios publicados por la agencia Ayer and Son's de Filadelfia hasta 1922, todos digitalizados, y los informes del servicio de Correos filipino, con detallada relación de periódicos editados, directores y rasgos, relaciones que llegan hasta los días de la II Guerra Mundial.

Mejor es el panorama bibliográfico, tanto en español como en inglés. Junto a la digitalización de algunos títulos clásicos, de difícil acceso, editados en los mismos años objeto de este estudio, en las últimas décadas son numerosos los estudios aparecidos en Filipinas sobre la evolución de su prensa, si bien es cierto que se percibe una infravaloración en ellos de la prensa en español, probablemente por el desconocimiento del idioma de la mayoría de los jóvenes autores.

\section{Reorganización tras la guerra (1899- 1903)}

El año 1899 marca el inicio de una nueva era para la prensa en Filipinas. El anterior, el año de la guerra hispano-norteamericana, ha sido muy difícil para el ejercicio del periodismo. En los meses iniciales serán cerrados por las autoridades españolas títulos sospechosos de simpatizar con los independentistas. Es el caso del Diario de Manila, veterano periódico surgido en 1848 , en cuya imprenta se localizan en febrero 
panfletos de los insurgentes. En los últimos meses del año, perdida la guerra por España, serán los diarios más partidarios de la vinculación de las islas a España los que cierren en tanto asoman tímidamente los periódicos nacionalistas. Cuando se firma el 10 de diciembre de 1898 el Tratado de París, que pone fin oficial a la guerra y ratifica el dominio norteamericano en las islas, de los periódicos que se imprimían al inicio del año apenas sobreviven en Manila el aséptico diario El Comercio, el periódico de la familia Loyzaga, que había surgido el 11 de octubre de 1869 y se adapta a los nuevos tiempos, la Revista Mercantil, de la misma empresa, y algún órgano secundario, como El Correo sino-anmanita, peculiar anuario sobre las misiones católicas en Asia. Fuera de la capital hay incluso menor continuidad, pues prácticamente solo registramos el mantenimiento de El Siglo (febrero de 1897-marzo de 1902), en Iloilo.

Las islas están pobladas entonces por casi ocho millones de personas, aunque esa población retrocede -hasta 1903- por los sucesivos conflictos. En vísperas de la guerra la población española se sitúa en torno a las 75.000 personas, tras ella se producirá una repatriación masiva y en Filipinas quedan, según las fuentes, entre 3.000 y 6.000 , la mitad de ellas en Manila. El influyente clero católico, por ejemplo, que en los días de la guerra suponen las 1.200 personas, no llega a 400 en 1903 (Rodao, 2011: 252-253). En estos años se considera que habla español o lo comprende en torno al $14 \%$ de la población de las islas, incluidos alrededor de los 200.000 mestizos. Es sin duda el idioma de la calle y el comercio; pero en 1898 no llega al diez por ciento la población escolarizada -con todo, uno de los niveles más altos de Asia-, y parte de la escolarización está a cargo de grupos religiosos, ahora en desbandada; además, en 1900-1901 llegan a las islas 650 maestros norteamericanos para impartir enseñanza en inglés y la legislación impuesta por los nuevos ocupantes contempla un proceso paulatino para que en 15 años toda la enseñanza se imparta en lengua inglesa.

En esa tesitura, la prensa que se crea en 1899 y años siguientes lo hará preferentemente en español, aunque con secciones en tagalo y otros idiomas filipinos, y muy secundariamente, salvo Manila, en inglés. En su mayoría, y mucho más fuera de la capital, son expresión del pueblo filipino, que desconoce el inglés, no de la exigua colonia española. Aflora una nueva y nutrida generación periodística en el país, pero es patente que permanecen también muchos protagonistas del periodismo filipino anterior a 1898: los Romero Salas, Del Pan, Loyzaga, Ravago, Utor, Campillá, Pellicena..., que adoptan distintas posturas ante el cambio.

En el año 1899, según Taylor (1927:36), aparecen 24 nuevos títulos en el país. Nueve de ellos estarán redactados en español, seis en inglés y nueve en distintos idiomas filipinos. En realidad, el número de periódicos aparecidos en este año es muy superior al estimado por Taylor, que ignora buena parte de la prensa editada fuera de Manila, y rebasa los 35 títulos. Entre los órganos bilingües una mayoría ofrecen la cabecera en español y un predominio de textos en este idioma: El filipino libre, que funda el médico 
Manuel Xerez Burgos (Manila, 1853-1937), La Voz del pueblo y, sobre todo, La Democracia, diario, que comienza el 16 de mayo, impulsado por el destacado físico y botánico Trinidad H. Pardo de Tavera Gorricho (Manila, 1857-1925), poco proclive a la cultura española. En este diario, llamado a alcanzar notable popularidad y ser hasta su extinción en 1917 el principal órgano pronorteamericano en español, leemos significativamente al iniciar su publicación:

Queremos la paz: somos filipinos y como tales deploramos que se derrame inútilmente la sangre de nuestros hermanos /.../ Creemos en los nobles propósitos de pueblo americano, y atendiendo al llamamiento de la comisión nos proponemos en La Democracia prestarle nuestra cooperación para el logro de las justas aspiraciones de nuestro propio pueblo.

No obstante, en La Democracia coincidirán varias sensibilidades respecto a España y su cultura y otro periodista decisivo en los primeros años del diario, Leoncio González Liquete (1877), por ejemplo, será uno de los impulsores de la Academia de la Lengua española en Filipinas.

Casi todos estos títulos, como El grito del pueblo, diario en principio, que representará al sector nacionalista liderado por Pascual $\mathrm{H}$. Poblete, serán mucho más críticos. Pero La Unión, de 1901, es otro periódico favorable a los norteamericanos y en sus páginas se publica el manifiesto de fundación del Partido Federal, que contempla como objetivo la integración de Filipinas en los EE UU como un estado más.

En la capital filipina surge en abril de 1899 El Noticiero de Manila, un diario vespertino moderado que se mantiene hasta 1904, dirigido por Joaquín Pellicena Camacho (Valladolid, 1879-París, 1938) y con su hermano Pedro en la redacción. Los Pellicena, padre e hijos, forman una familia periodística muy relevante en los inicios del siglo XX. Libertas (7 de julio de 1899-31 de enero de 1918), cubre al poco el espacio de la prensa católica; diario muy conservador, lo crea un grupo de dominicos encabezado por Buenaventura García de Paredes y el arzobispo de Manila Bernardino Nozaleda -que aporta 2.000 pesos-, lo dirige primero Manuel Ravago Neri (Cagayan, 1870-San Pablo, 1937), asiduo colaborador de la prensa católica manileña hasta su muerte; luego estará a su frente Ángel Goicouría. Cesa hacia el final de la I Guerra Mundial, suspendido por el gobierno norteamericano por sus manifiestas simpatías hacia los Imperios Centrales. Órgano católico será asimismo La estrella de Antipolo-nombre del principal santuario católico del país-, quincenal que comienza en agosto de este año y se editará hasta 1908. La iglesia católica se enfrenta en los primeros años a la pérdida de efectivos, el generalizado anticlericalismo de la nueva prensa, la arraigada demanda de una iglesia más enraizada en el pueblo y la aparición de la Iglesia Filipina Independiente, escisión que rechaza la autoridad del Papa y tiende a configurar una iglesia nacional. Reacciona con cierta lentitud: hasta 1906, por ejemplo, no será nombrado un obispo nacido en Filipinas. 
El Progreso, que asoma en junio, es un proyecto de la familia Del Pan -anteriormente dueña del Diario de Manila-, que dirigido por Víctor del Pan se mantiene -desde 1901 como El Adelanto- hasta 1904. El veterano escritor masón Juan Utor Fernández crea en 1899 El Liberal y luego redacta La Patria, que representan la tendencia más demócrata dentro del abanico de nuevas publicaciones. La masonería tendrá destacada presencia en la prensa filipina en español hasta los años veinte y La Patria, que se edita hasta 1904, será algún tiempo, dirigida por Miguel Zaragoza, órgano del fugaz Partido Liberal.

En diciembre comienza El Correo de Oriente, que anima José María Romero Salas. Tiene corta vida, pero Salas relanza el Diario de Manila en 1900, y luego, el 1 de abril de 1902, con mucho más éxito, pues alcanza a 1930, creará su propio periódico, El Mercantil, y dirigirá la Cámara de Comercio española en Manila. Será persona muy popular y hoy una calle en Manila lleva su nombre. Convierte a El Mercantil en el órgano más leído por la colonia española en Manila durante tres décadas. El Comercio, dirigido por José Ageo de Loyzaga (Manila, 1864-1926) desde 1894, es vespertino muy aséptico, que sabe adaptarse a la nueva situación. La empresa edita hasta junio de 1903 la veterana Revista mercantil -había surgido en 1865-, semanal. El nuevo Diario de Manila no alcanza el éxito de su anterior etapa, en 1905 edita el suplemento literario "Los domingos del Diario de Manila», pero cesa por entonces. Romero Salas conoce la cárcel por un artículo en este diario, donde censura al dirigente Felipe Buencamino, que de líder insurgente pasa a federalista pronorteamericano.

Pero 1899 es también el año de inicio de la guerra de los nacionalistas filipinos contra el nuevo ocupante, EE UU. Los filipinos -que oficialmente han proclamado su independencia en junio de 1898- han visto como se firmaba en diciembre ese Tratado de París sin contar con ellos ni otorgarles autonomía. Se inicia una guerra en condiciones muy desiguales, que concluye en 1902 con la rendición del líder filipino Emilio Aguinaldo. Ya semanas antes los independentistas filipinos lanzan diversos periódicos, con neto dominio del español en sus páginas. En junio de 1898 Clemente José Zulueta funda La Libertad, fugaz. Durante lo que se llamará la Primera República Filipina (1899-1902), cuya constitución declara el español idioma oficial, veremos aparecer títulos como La Independencia, en Manila, el 3 de septiembre de 1898, diario, y el 28 de diciembre La Revolución en Iloilo, un semanario. De su lado, uno de los líderes de esa república nativa, Pedro Paterno (Manila, 1857-1911), impulsará La República filipina, pronto suspendido por el gobierno norteamericano. Ya en 1899 se imprime en Malolos, capital de la efímera república, en el interior de la isla de Luzón, El Heraldo de la Revolución. Se transformará en Gaceta de Filipinas, como órgano oficial de la efímera república. Los nacionalistas promoverán incluso algún periódico infantil, como El Aprendiz, en 1900. No faltan periódicos migrantes, por los avatares de la guerra, como Columnas Volantes, que se imprime en 1899 en la región de Mabini, al sur de la isla de Luzón. 
La Independencia, el más relevante de todos ellos, se mantendrá únicamente hasta el 24 de noviembre de 1899, apenas un año; sus instalaciones serán destruidas por el gobierno norteamericano. Lo funda el general insurgente Antonio Luna Novicio y será su redactor jefe y luego -tras la muerte de aquel- su director, Rafael Palma Velázquez (Manila, 1874-1939), que tras una intensa vida periodística a inicios del siglo XX es elegido rector de la Universidad de Filipinas. A sus páginas asoma parte de esa generación de jóvenes nacionalistas, escritores y políticos, que luego redactarán distintos medios, como Cecilio Apóstol (Manila-1877-1938), poeta en español, que colabora asimismo en La Fraternidad o luego El Renacimiento. La línea del diario aparece clara desde el primer número:

Nosotros defenderemos la independencia de Filipinas porque es la aspiración de un país que ha llegado a su mayor edad; y cuando un pueblo se levanta como un solo hombre para protestar, arma al brazo, contra una política de opresión e injusticia, manifiesta vitalidad suficiente para vivir libre.

La suspensión de La Independencia (reaparecerá fugazmente en 1906-1907, dirigida ahora por Macario A. González) lleva al mismo grupo a crear en Cebú otro periódico nacionalista, El Nuevo Día, que se editará en 1900-1901. Su impulsor y financiador es un joven Sergio Osmeña, futuro presidente del país. Lo redacta asimismo Palma, que en el número del 7 septiembre de 1900 escribe sobre España:

Hay que sentar que nuestro espíritu es muy distinto. La naturaleza, así como nos ha dotado de otra piel y otra sangre, nos ha dado también distintas cualidades y potencias. El alma española los ha vivificado, pero obsérvanse determinadas resistencias, impulsos contrarios, influidos por la naturaleza, el clima, los mismos componentes físicos y psíquicos. ¿Cabe la asimilación? No. En la naturaleza no se combinan lo positivo y negativo, se rechazan siempre. El alma española tiene vicios y defectos, cuyos gérmenes heredamos. Depurándola, podemos tener lo que quisiéramos. El alma española representa el antiguo culto á las ideas puras, á las ideas inmortales, las que hacen los pueblos, las que mantienen el eterno rejuvenecimiento de la humanidad en la quebrantada postración de nuestros días, consumidos por la fiebre y nostalgia del becerro de oro.

El cierre de El Nuevo Día obliga a lanzar otro periódico a los nacionalistas, ahora en Manila, será El Renacimiento, con ediciones en español y tagalo, un diario que comienza en septiembre de 1901 y se mantendrá una década, siempre en el filo de la navaja con las autoridades norteamericanas. Con Rafael Palma será figura decisiva en los primeros tiempos su hermano José. El diario tendrá desde 1903 como director a Fernando María Guerrero (Manila, 1873-1929), que como casi todo el grupo une a la pasión periodística y política la literaria. No es modesto el periódico en su presentación: 
Hecho por filipinos, casi todos ellos de pura raza, El Renacimiento constituye la prueba más concluyente de la capacidad de los naturales de las Islas, no solo como escritores, sino como hombres de gran sentido político. Colaboran en este diario, el de mayor circulación del Archipiélago, las plumas más notables del país.

El diario, como destaca Gloria Cano (2011: 414-415), desarrolló en 1903 una campaña en pro de la consideración del español como idioma nacional en Filipinas en detrimento del inglés. En el editorial del 12 de mayo de ese año, titulado «El castellano como lenguaje oficial», subraya que "la lengua de un pueblo no se improvisa. Los esfuerzos del Gobierno no han dado al inglés el carácter de generalización necesaria para ser oficial. Es indispensable una generación por lo menos para asimilar un idioma extraño. La declaración del inglés como lenguaje oficial equivaldría a excluir prácticamente a los filipinos de sus actuales puestos».

El mismo año en que surge El Renacimiento, la administración norteamericana aprueba, el 4 de noviembre de ese 1901, lo que se llamará Ley de Sedición, que prohibe defender, por la palabra o la imprenta, la independencia de Filipinas. Se aplicará en numerosas ocasiones.

No son los únicos títulos con simpatías nacionalistas en los años iniciales de la nueva etapa, las evidencian también, en Manila, La Aurora, nuevo órgano de Poblete, que anima Pedro Aunario (Manila, 1880-1945) en 1899; La Fraternidad, que funda en 1900 Alfonso Montes, o La Luz, de 1900. Fuera de Manila brota también una prensa nacionalista, casi siempre escrita en español, que desde luego tendrá muchos problemas con las nuevas autoridades norteamericanas, pero también con la jerarquía eclesiástica, vista por lo general como defensora del colonialismo español. El Instructor, por ejemplo, es un pequeño periódico quincenal surgido en Dagupán en 1899 y dirigido por un sacerdote heterodoxo, Adriano Garcés, no llega al año de vida. En Aparri, surgirá en 1900 El Porvenir de Aparri, bilingüe (español y cagayan), también con fuerte anticlericalismo. Significativo es lo ocurrido en Cebú, la segunda ciudad de las islas. Allí, dos hermanos, Vicente (Cebú, 1877-Manila, 1950) y Filemón Sotto (18721966), nacionalistas e impresores, crean en 1899 La Justicia, suspendido de inmediato por las autoridades ocupantes. Al poco lanzan El Nacional, al que ocurre lo mismo, y que le vale a Vicente Sotto dos meses de cárcel; cuando sale, ya en 1900, crea un tercer periódico, El Pueblo, semanario como los anteriores y algo más duradero, pero que acaba siendo igualmente suspendido y obliga a Vicente a exiliarse en Hong Kong, de donde solo regresará, más de diez años después, para lanzar entonces, 1912, La Independencia, semanario, en Manila. Filemón, más moderado, o más cauto, crea en 1899 El Imparcial, pero años después, en 1907, algo suavizada la censura, funda El Nacionalista, de título explícito. Deja la primera línea del periodismo por la acción 
política y en 1916 es elegido senador, luego será redactor de la constitución filipina de 1935.

En Iloilo el 28 de junio de 1900 comienza El País, que funda Ramón Avanceña (Molo, 1872-Manila,1957), futuro presidente del Tribunal Supremo filipino; no tendrá larga vida, parece utópico en esa coyuntura: las autoridades norteamericanas suspenden el periódico el 8 de septiembre. Algo parecido ocurre con Las Noticias, que asoma el 2 de enero de 1901 y tiene muy corto recorrido. Pero no faltan en la ciudad nuevas iniciativas. En 1903 surge La Voz de Bisayas, diario. Antes, en 1899-1900 se ha editado la Revista Comercial, que no es, como pudiera parecer, una publicación de economía, sino un trisemanario de información general.

En la isla de Bohol comienza a editarse el 15 de mayo de 1899, La Oportunidad, que tendrá igualmente corta y azarosa existencia.

\section{Una edad de plata: 1903-1920}

Concluida la guerra filipino-norteamericana, la prensa se asienta en el país, que comienza a crecer en población, y la editada en español -que se mantiene como idioma oficial y será, por ejemplo, el idioma de los tribunales hasta 1913- conoce una relativamente buena coyuntura, de forma que reaparece incluso la prensa satírica con títulos como El Tío Paco, semanario que comienza en 1902, dirigido por Joaquín Pellicena Camacho, además de una prensa especializada como Mercurio, revista comercial que dirige Francisco Campillá Casades, o la titulada Revista de Tribunales. El Tío Paco, que no llega al año de vida, defiende sin rebozo la herencia española, pero EI Nuevo Diógenes, que comienza en abril de 1901, es claramente pro-norteamericano. En 1899 había surgido de forma fugaz, The kon gotas, visible sucesor de The kon leche, extinguido en 1898. En 1903 se editan en Manila una docena de diarios, de ellos 7 en español, 3 en inglés y 2 bilingües. Aunque la guerra formalmente termina en 1902, se mantienen núcleos de resistencia durante años y la administración norteamericana vigila sobre todo a los periódicos nacionalistas.

También fuera de la capital reaparece la prensa en español y es inicialmente muy escasa la redactada en inglés. En Cebú, aparte de los títulos nacionalistas ya aludidos, en 1903 se crea El País, trisemanario, un periódico moderado que funda y dirige Joaquín Pellicena López (Barcelona, 1856-Buenos Aires, 1916), padre de Pellicena Camacho; en 1904 lo hace La Opinión y en 1907, con El Precursor, bilingüe, asoma la familia Cuenco, propietaria de la Imprenta Rosario, que será decisiva en el periodismo local -y la política- durante varias décadas. Lo funda Mariano Albaw Cuenco, pero en seguida la persona clave será su hijo, Mariano Jesús Cuenco (Cebú, 1888-Manila, 
1964), que será destacado líder del Partido Nacionalista filipino y en 1946 presidirá el senado de una Filipinas ya independiente. El periódico, bisemanal en principio, pero que llegará a diario, se mantiene hasta 1941, cesa con el inicio de la II Guerra Mundial. Periódicos, por lo general más fugaces, de Cebú serán asimismo Nueva era, trisemanario de 1902, El Anunciador, semanario de 1907, y The Curier, semanario sabatino, que si bien muestra cabecera en inglés tiene contenido bilingüe pero con mayoría de textos en español, comienza en 1907 y se mantiene un trienio. En la cercana ciudad de Argao veremos editarse, con más fugacidad, La Voz de Argao, en 1906, y La Solidaridad, en 1907.

En Iloilo Julio P. Hernández promueve y dirige El Tiempo, federalista, es decir, pro norteamericano, que comienza en 1900, y se editará asimismo más fugazmente $L a$ Aurora. En Cagayan asoma El Porvenir, trisemanario, y en Bacolod La Igualdad. En Nueva Cáceres surgirá en 1902 La Paz, semanario trilingüe, de título explícito, pues viene a ser el lema de los pronorteamericanos, en el año en que concluye la guerra filipina. Lo funda Francisco Álvarez y su ideología facilita sin duda su mantenimiento al menos un lustro. Es patente que el Partido Federal, mimado por la administración norteamericana, organiza una red con cabeceras afines en numerosas ciudades; con pragmatismo, serán prácticamente todos periódicos en español.

En buena parte, los impulsores de esta prensa son impresores, algunos establecidos ya en años precedentes, otros lo harán ahora. En Iloilo, por ejemplo, José González Paramós, dueño de la imprenta «La Editorial», crea en 1903 con Manuel de la Portilla Nuevo Heraldo, diario en español, que asimismo codirige. El periódico se va a mantener durante dos décadas. En su establecimiento se realizarán otros títulos, como la Revista Católica, órgano semanal del Centro Católico, que comienza en 1903 y consigue audiencia regional. Nuevo Heraldo difunde en torno a los 700 ejemplares, Revista Católica los 400. Otro caso muy significativo, años después, será el de Flavio Zaragoza Cano, que funda en 1914 en Legazpi el bisemanario Heraldo de Bicol, y para garantizar su continuidad crea la Imprenta Monserrat. El periódico se editará en efecto hasta la guerra. Zaragoza había redactado con anterioridad en Iloilo La nueva fuerza y desempeñará tareas muy heterogéneas, incluida la de traductor en los tribunales de Iloilo.

En Manila, el fugaz Partido Conservador, visto por las autoridades norteamericanas como simpatizante de España, crea en 1901 el Diario de Filipinas, que dirige Macario Adriático González. Partido y periódico duran poco. El nacionalismo se dota en 1906 de un nuevo órgano diario oficial, Soberanía Nacional, de corta vida, y luego de diversos periódicos menores, con semanarios como El Nacionalismo, que se edita en Manila apenas unas semanas en 1906-1907, o La Asamblea, de 1908, otro periódico promovido por Paterno, además de mantener, más independiente, El Renacimiento. 
El 30 de octubre de 1908 este diario, por entonces el más difundido en las islas, publica el editorial "Aves de rapiña», escrito por Fidel Reyes, en una etapa en que lo dirige Teodoro M. Kalaw (Lipa, 1884-Manila, 1940), donde se censuran las prácticas depredadoras de la administración norteamericana y alude al Ministro del Interior, Dean Worcester. En ese editorial se puede leer:

Hay hombres que, además de ser águilas, reúnen en sí las características del buitre, del búho y del vampiro. Subiendo a las montañas de Benguet para clasificar y medir cráneos de igorrotes y estudiarlos y civilizarlos y sorprender al vuelo, con ojo de ave de rapiña, donde se encuentran los grandes yacimientos del oro, la presa oculta entre los montes solitarios, para apropiárselos después gracias a facilidades legales hechas y deshechas al antojo, pero siempre en beneficio propio. Autorizando a despecho de leyes y ordenanzas una matanza ilegal de ganado enfermo, para sacar beneficio de la carne infecta y podrida que el mismo estaba obligado a condenar en virtud de su posición oficial. Presentándose en todas las ocasiones con el ceño fruncido del sabio que consume su vida en los misterios del laboratorio de ciencia, cuando toda su labor científica se reduce a desecar insectos e importar huevas de peces como si los peces de este país fueran menos nutritivos y menos ricos, de tal modo que valiera la pena de sustituirlos con especies venidas de otros climas. Dando un impulso admirable al descubrimiento de veneros de riqueza en Mindoro, en Mindanao y demás puntos vírgenes del archipiélago con el dinero del pueblo y con el pretexto de bien público, cuando en rigor se trata de poseer todos los datos y la clave de la riqueza nacional en provecho personalísimo como se demuestra por la adquisición de inmensas propiedades registradas con nombres ajenos. Promoviendo por medio de agentes y consocios secretos la venta a la ciudad de terrenos sin valor por cantidades fabulosas que los padres de la ciudad no se atreven a rehusar por el temor de disgustar a quien va detrás de la moción, y que no rehúsan por lo que les conviene. Patrocinando la concesión de hoteles en sitios terraplenados con la perspectiva de enormes utilidades, a expensas de la sangre del país.

Se desencadena un largo y complejo proceso judicial contra toda la redacción y propiedad del periódico, con 12 personas procesadas, y se tambalea el diario, que tiene también una edición en tagalo. En enero de 1910 llegan unas sanciones inusualmente duras y la suspensión por la administración norteamericana ${ }^{1}$. Naturalmente, los periódicos afines al gobierno norteamericano lo acusan reiteradamente de odio a los Estados Unidos. Kalaw será, curiosamente, ministro de

\footnotetext{
${ }^{1}$ El Renacimiento llegó a convertirse en toda una obsesión para la Administración norteamericana. En 1910 la Corte Suprema filipina editó un volumen de 174 páginas recopilando todas las quejas contra el periódico [Disponible en www.archive.org/details/cu31924073778890]
} 
Interior en 1920, con la administración autónoma filipina, y director de la Biblioteca Nacional.

Al finalizar la década inicial del siglo, Manila dispone de media docena de diarios en español, que abarcan casi todo el arco ideológico del país. El Comercio y El Mercantil son periódicos poco políticos, pero con apreciable audiencia. Aquel dirigido por su propietario, José Ageo Loyzaga, y este por José María Romero Salas. Libertas es el diario católico, cabecera de un red de prensa afín relevante, con varias revistas y periódicos comarcales -como La Juventud, semanario de 1904, en Cebú-, pues la iglesia católica ha de responder al incremento de la propaganda protestante, con publicaciones presbiterianas y metodistas, y, de otro lado, la ya aludida aparición en 1902 de la denominada Iglesia Filipina Independiente, una iglesia nacional «Aglipayan»- que mantendrá también sus órganos, como el semanario en español titulado precisamente Iglesia filipina independiente, surgido en 1902. Esta iglesia tiene claras simpatías en periódicos nacionalistas como El Grito del pueblo y, con matices, El Renacimiento.

La Democracia, de su lado, representa como vimos la aceptación del poder norteamericano. Trinidad H. Pardo de Tavera, su promotor -cofundador del aludido Partido Federal, que representará esa corriente-, se mantiene a su frente una década; luego lo dirigirán, entre otros, Hugo Salazar, Gaudencio Eleizegui y sobre todo Manuel Bernabé, destacado escritor en lengua española. Cuando Pardo de Tavera fallece en 1927, otro destacado periodista, poco pronorteamericano, Teodoro M. Kalaw, desde las columnas de La Vanguardia, le dedica el 9 de septiembre una columna donde afirma:

Pardo de Tavera era entre los nuestros, el más grande, el más decidido y el más honrado campeón del americanismo, del americanismo sano, que no es otro que la importación de lo mejor de la civilización americana. -«ldeas americanas necesitamos», decía Pardo cuando todavía estaba en el poder, "prácticas americanas, instituciones americanas y, especialmente, idioma americano». Estos propósitos los encarnó él (Pardo) en una organización política que, al fracasar en el pueblo, mató a su vez el ideal que la caracterizaba: la anexión.

Esa organización política es el Partido Federal, que desaparece en 1907.

El cierre de El Renacimiento lleva a la creación de La Vanguardia (y de Taliba, en tagalo), en febrero de 1910, impulsada por el último editor de El Renacimiento, Martín Ocampo (1852-1927), que morirá exiliado en Guam, y con Fernando M. Guerrero de director. Años después, en 1916, el periódico pasará a manos de Alejandro Roces y conocerá una etapa de menor militancia y una discreta independencia. El diario llegará hasta los días de la II Guerra Mundial. El nacionalismo se refuerza también en 1910 con El Ideal, diario que dirige Arsenio N. Luz, uno de los grandes impulsores del carnaval 
manileño, y donde el escritor Jaime C. de Veyra (Tanawan, 1873-2963) mantiene una leída sección, «Efemérides filipinas». Se editará hasta 1922.

Junto a los diarios, no falta una prensa satírica en lengua española o en español y otros idiomas, como El Hisopo, 1906, que introduce textos en chabacano, o Chispazos, que se imprime en 1907-1908, dirigida por José Sedano Colenge. Lipag Kalabaw, pese a su cabecera en tagalo, es un satírico en lengua española asimismo de 1907-1908. Pero son títulos que, al contrario que los diarios, no se consolidan. Nacen los primeros periódicos orientados a los trabajadores, como La redención del obrero, del que aparecerán 20 números en 1903-1904. Su creador es Isabelo de los Reyes, uno de los promotores de la Iglesia filipina independiente -de hecho se oferta conjuntamente con el semanario órgano de ésta-. De ideario muy contradictorio, en el número dos, del 15 de octubre, el editorial con el que se abre el número, titulado «Redimamos a la obrera», concluye con esta pintoresca reivindicación:

Basta de esclavitud. Redimamos a las pobres mujeres filipinas formando asociaciones de damas cristianas que persigan este humanitario objeto, así como en Europa ya están formándose otras análogas encabezándolas las emperatrices, reinas, princesas y demás señoras ilustres.

Le sucede, aunque por poco tiempo, El Trabajo.

La batalla de los idiomas y su futuro se libra desde luego en la escuela, dominada por el inglés. No hay siquiera periódicos pedagógicos para favorecer la enseñanza en español. En 1902 apuntamos, pero parece iniciativa aislada, una edición en España para Filipinas de El mentor de los niños, enciclopedia para la primera enseñanza, que ha redactado años antes el pedagogo asturiano Acisclo Fernández Vallín y Bustillo. En diciembre de 1904, por ejemplo, asoma The Filipino Teacher, mensual, que distribuye el gobierno norteamericano gratuitamente. Luego será órgano de la Asociación Filipina de Profesores, dirigido por Vicente Díaz. En sus primeros años se redactará en inglés y español, luego solo en inglés. En julio de 1907 Filipinas celebra sus primeras elecciones para elegir un parlamento autónomo, 80 miembros, el Partido Nacionalista obtiene 59 de ellos, una gran victoria, y el Partido Nacional Progresista, heredero del Federal, 16. En octubre se constituye la primera Asamblea, que presidirá Sergio Osmeña, tan perseguido por las autoridades norteamericanas cuando redactaba en Cebú El Nuevo Día.

No obstante las ausencias señaladas, en la primera década del siglo surgirán en Manila numerosas y en algún caso notables publicaciones especializadas en español. En 19031904 Manuel Artigas Cuerva dirige El Maquinista, órgano de la Asociación de Maquinistas Terrestres y Navales de Filipinas. En 1904 comienza el Boletín de la Cámara de Comercio Filipina, que se edita hasta 1913. De mayo de 1905 data la Revista histórica de Filipinas, mensual. En 1905-1905 se edita el curioso Boletín de la 
Clínica Electroterápica, que dirige el médico Antonio de Asís. En 1907 se imprime Vida Filipina, semanal. También como publicación ilustrada surge en 1908 la Revista Popular, mensual. En ese mismo año, 1908, aparecen la Revista Científica de Filipinas, mensual asimismo, Domus Aurea, de corta vida, Enciclopedia Filipina, que edita su primer número en febrero, y sobre todo Excelsior, dirigida por Luis Sors, mensual en principio, luego decenal, será la más destacada revista ilustrada y de amenidades en español hasta los días de la II Guerra Mundial y desempeña un papel relevante en el seno del periodismo en lengua española. En 1908 comienza también a editarse la Biblioteca Nacional Filipina, mensual, que dirigirá el historiador Manuel Artigas Cuerva (1866-1945) y con la historia dominando en sus contenidos; cesa en 1911. Igualmente con contenido cultural y con gran apertura surge en 1910 Cultura Filipina, órgano de una asociación del mismo nombre, mensual asimismo y dirigida por Narciso Rangel Rodríguez. Dispone de imprenta propia y organiza al mismo tiempo una pequeña editorial, pero cesa en 1914.

También de 1910 data la Revista filipina de Medicina y Farmacia, órgano del Colegio de Médicos y Farmacéuticos, mensual, y llamada a superar las tres décadas en publicación. Es otra publicación que solo cesa en 1941, con la guerra. De excelente nivel, publica por ejemplo notables trabajos sobre remedios para la enfermedad del beri-beri. Ese mismo 1910, cuando cesa el diario El Renacimiento, surge la revista semanal ilustrada Renacimiento Filipino, impulsada por Martín Ocampo, que se mantiene al menos hasta 1912. Al concluir la década, como refleja el cuadro no 1 , la prensa filipina en español o bilingüe supera los veinte títulos, de un total aproximado de 50 publicaciones en edición.

Cuadro no 1.- La prensa en español de Filipinas en 1910

\begin{tabular}{|c|c|c|c|c|c|c|}
\hline Título & \multicolumn{2}{|c|}{ Ciudad } & $\begin{array}{l}\text { Frecuenci } \\
\text { a de } \\
\text { aparición }\end{array}$ & $\begin{array}{l}\text { Fundació } \\
\text { n }\end{array}$ & $\begin{array}{l}\text { Idioma } \\
\mathrm{s}\end{array}$ & $\begin{array}{l}\text { Rasgos. } \\
\text { Difusió } \\
\text { n }\end{array}$ \\
\hline El Adalid & Iloilo & Diario & 1907 & Español & $\begin{array}{l}\text { Inform } \\
\text { gener } \\
\text { Nacior }\end{array}$ & ición \\
\hline $\begin{array}{l}\text { El Atalaya de } \\
\text { Negros }\end{array}$ & Bacolod & Diario & 1910 & Español & $\begin{array}{l}\text { Inform } \\
\text { gener }\end{array}$ & ción \\
\hline $\begin{array}{l}\text { Biblioteca } \\
\text { Nacional } \\
\text { Filipina }\end{array}$ & Manila & Mensual & 1909 & Español & Cultur & \\
\hline $\begin{array}{l}\text { Boletín de la } \\
\text { Cámara de } \\
\text { Comercio } \\
\text { filipina }\end{array}$ & Manila & Mensual & 1904 & Español & Come & \\
\hline Boletín oficial & Manila & Trisemar & na 1905 & Español e & Inform & ción \\
\hline
\end{tabular}




\begin{tabular}{|c|c|c|c|c|c|}
\hline & & I & & Inglés & oficial \\
\hline El Comercio & Manila & Diario & 1869 & Español & $\begin{array}{l}\text { Información } \\
\text { general. } \\
\text { Conservador } \\
\text { Independiente }\end{array}$ \\
\hline The Courier & Cebú & Semanal & 1907 & $\begin{array}{l}\text { Español e } \\
\text { inglés }\end{array}$ & $\begin{array}{l}\text { Información } \\
\text { general }\end{array}$ \\
\hline $\begin{array}{l}\text { Cultura } \\
\text { Filipina }\end{array}$ & Manila & Mensual & 1908 & Español & Cultura \\
\hline La Democracia & Manila & Diario & 1899 & $\begin{array}{l}\text { Español y } \\
\text { tagalo }\end{array}$ & $\begin{array}{l}\text { Información } \\
\text { general. } \\
\text { Nacionalista }\end{array}$ \\
\hline Excelsior & Manila & Decenal & 1908 & Español & $\begin{array}{l}\text { Literatura y } \\
\text { amenidades. } \\
2.000\end{array}$ \\
\hline $\begin{array}{l}\text { Filipino } \\
\text { Teacher }\end{array}$ & Manila & Mensual & 1904 & $\begin{array}{l}\text { Inglés y } \\
\text { español }\end{array}$ & Educación \\
\hline El Ideal & Manila & Diario & 1910 & Español & $\begin{array}{l}\text { Información } \\
\text { general. } \\
\text { Nacionalista }\end{array}$ \\
\hline Libertas & Manila & Diario & 1899 & Español & $\begin{array}{l}\text { Información } \\
\text { general. Católico }\end{array}$ \\
\hline El Mercantil & Manila & Diario & 1902 & Español & $\begin{array}{l}\text { Información } \\
\text { general. } \\
\text { Independiente }\end{array}$ \\
\hline $\begin{array}{l}\text { Mindanao } \\
\text { Herald }\end{array}$ & Zamboanga & Semanal & 1903 & $\begin{array}{l}\text { Inglés y } \\
\text { español }\end{array}$ & $\begin{array}{l}\text { Información } \\
\text { general }\end{array}$ \\
\hline Nuevo Heraldo & Iloilo & Diario & 1903 & Español & $\begin{array}{l}\text { Información } \\
\text { general. } \\
\text { Independiente }\end{array}$ \\
\hline LaPaz & $\begin{array}{l}\text { Nueva } \\
\text { Cáceres }\end{array}$ & $\begin{array}{l}\text { Semanari } \\
\text { o }\end{array}$ & 1902 & $\begin{array}{l}\text { Español, } \\
\text { inglés y } \\
\text { bicolano }\end{array}$ & $\begin{array}{l}\text { Información } \\
\text { general. } \\
\text { Independiente }\end{array}$ \\
\hline $\begin{array}{l}\text { Philippine } \\
\text { Agricultural } \\
\text { Review }\end{array}$ & Manila & Trimestral & 1908 & $\begin{array}{l}\text { Inglés y } \\
\text { español }\end{array}$ & Agricultura \\
\hline $\begin{array}{l}\text { Philipino Free } \\
\text { Press }\end{array}$ & Manila & $\begin{array}{l}\text { Semanari } \\
\text { o }\end{array}$ & 1908 & $\begin{array}{l}\text { Inglés y } \\
\text { español }\end{array}$ & $\begin{array}{l}\text { Independiente. } \\
6.750 \\
\text { ejemplares. }\end{array}$ \\
\hline El Precursor & Cebú & Bisemanal & 1907 & $\begin{array}{l}\text { Español y } \\
\text { bisayano }\end{array}$ & $\begin{array}{l}\text { Información } \\
\text { general. }\end{array}$ \\
\hline
\end{tabular}




\begin{tabular}{|c|c|c|c|c|c|}
\hline \multirow[b]{2}{*}{$\begin{array}{l}\text { Renacimiento } \\
\text { filipino }\end{array}$} & \multirow[b]{2}{*}{ Manila } & \multirow[b]{2}{*}{ Semanal } & \multirow[b]{2}{*}{1910} & \multirow[b]{2}{*}{ Español } & Nacionalista \\
\hline & & & & & Revista ilustrada \\
\hline $\begin{array}{l}\text { Revista } \\
\text { Científica de } \\
\text { Filipinas }\end{array}$ & Manila & Mensual & 1908 & $\begin{array}{l}\text { Español e } \\
\text { inglés }\end{array}$ & $\begin{array}{l}\text { Divulgación } \\
\text { científica. } 2.000\end{array}$ \\
\hline El Tiempo & Iloilo & Diario & 1900 & Español & $\begin{array}{l}\text { Federalista. } \\
1.000 \text { ejemplares }\end{array}$ \\
\hline La Vanguardia & Manila & Diario & 1910 & Español & $\begin{array}{l}\text { Información } \\
\text { general. } \\
\text { Nacionalista }\end{array}$ \\
\hline \multicolumn{2}{|c|}{$\begin{array}{l}\text { (Estilo } \\
\text { RiHC_CuerpoTextoTabl } \\
\text { a) }\end{array}$} & Celda 2.1 & Celda 3.1 & & \\
\hline Celda 1.2 & & Celda 2.2 & Celda 3.2 & & \\
\hline Celda 1.3 & & Celda 2.3 & Celda 3.3 & & \\
\hline Celda 1.4 & & Celda 2.4 & Celda 3.4 & & \\
\hline Celda 1.5 & & Celda 2.5 & Celda 3.5 & & \\
\hline
\end{tabular}

Los años diez permiten, gracias al crecimiento demográfico y -con altibajoseconómico, pero también la mayor estabilidad política, una decidida expansión de la prensa en el país. Entre 1910 y 1920 se dobla prácticamente el número de títulos y publicaciones, que al finalizar la década supera ya claramente el centenar. El español conserva buen número de cabeceras, y ofrece clara mayoría entre los diarios, pero en la prensa especializada el inglés compite abiertamente con el castellano, que se mantiene como idioma oficial pero encuentra crecientes dificultades en las escuelas y en otros ámbitos. En Manila se editan de promedio siete diarios en español. El núcleo más estable está compuesto por dos veteranos periódicos conservadores moderados, El Comercio y El Mercantil, y el diario católico Libertas, que difunde unos 3.000 ejemplares, y que suspendido en 1918 por las autoridades será sucedido a los pocos meses por La Defensa, que aunque tendrá menos éxito se mantendrá como cotidiano algo más una década. La Democracia, animado por Manuel Bernabé, defiende ahora al Partido Progresista, nacionalista moderado. A su izquierda queda Consolidación Nacional, que surge en 1913 y dirige Pedro Gil (Cavite, 1889-Manila, 1965), nacionalista, alcanza en sus mejores momentos los 5.000 ejemplares; la misma empresa edita desde 1915 The Independent, semanario en inglés y español, que dirige Vicente Sotto, regresado del exilio; Gil ha sido antes el animador también de un 
semanario avanzado, Los Obreros. Nacionalistas son asimismo, en distintos niveles, El Ideal y La Vanguardia, que dirige Fernando María Guerrero y afirma superar los 5.900 ejemplares.

Al final de la década se producen cambios relevantes en el seno de la prensa nacionalista. Cesa Consolidación Nacional, que en 1918 se transforma en El Debate, que asume la numeración de su predecesor, entre sus directores iniciales estarán Francisco Verona y Ramón Torres. Difunde en sus primeros tiempos en torno a los 4.500 ejemplares. Ambos, claramente vinculados al incipiente movimiento obrero filipino, acercan el diario a los sectores obreros, sobre todo de Manila y la isla de Negros. El sector más nacionalista crea en paralelo un nuevo diario en español, $L a$ Nación, que dirigirán Pedro Gil y luego Gregorio Perfecto (Mandurriao, 1891-Manila, 1949) y se imprime hasta 1923. Será el diario más conflictivo en esos años para la administración norteamericana y supera los 5.000 ejemplares. Perfecto, jurista, combate la corrupción lo que le acarrea numerosas sanciones. En 1945 presidirá el Tribunal Supremo. En paralelo, El Filipino es un diario que impulsa Claro M. Recto (Tiálong, 1890-Roma, 1960) y redacta un joven Enrique K. Laygo (Lipa, 1897-Manila, 1932); Recto será uno de los impulsores del Partido Demócrata y destacado escritor en lengua española, al igual que Laygo.

La prensa en español sigue agrupada visiblemente en dos sectores, el nacionalista, que se expresa en castellano o lenguas locales, y la que defiende con matices la herencia y la cultura española, o la religión católica. En un artículo publicado en marzo de 1918 en The Philipine Review/Revista Filipina, el periodista Joaquín Pellicena subraya que los diarios "políticos» filipinos se expresan en español, y cita a El Ideal, como órgano oficial del Partido Nacionalista; La Nación, como órgano del Partido Demócrata, y La Vanguardia como nacionalista independiente. La Democracia, representa un caso casi aislado de diario pronorteamericano pero en lengua española, y cesa al concluir la década. Tiene un continuador, en The Philippines Herald, que comienza en 1920, pero ya, significativamente, en inglés. Lo promueve el futuro presidente Manuel L. Quezón. Hacia 1920 la prensa diaria de Manila en español alcanza en conjunto los 30.000 ejemplares cotidianos y supera claramente a la redactada en inglés o tagalo; pero es su canto de cisne.

Los diarios en español no se circunscriben a Manila, sino que aparecerán con cierto vigor en otras ciudades. En Bacolod, por ejemplo, veremos imprimirse en $1910 \mathrm{El}$ Atalaya de Negros, diario independiente que se editará durante un lustro, dirigido por su propietario, Niceto López González. En 1914 será sucedido por La Restauración, que se mantiene hasta 1919, bajo dirección de José López Asunción, y en 1917 por El Noticiero de Negros, que dirige Ramón L. Navas.

En Cebú tendremos, además de El Precursor, de la familia Cuenco, ya aludido, La Revolución, en español y cebuano/bisayano, desde 1910, un duradero trisemanario 
nacionalista -cesa en 1941, con el estallido de la Guerra- que impulsa Filemón Sotto. En 1913 comienza La Tribuna, impulsado a su vez por Manuel C. Briones (Cebú, 18931957), abogado y político, que posteriormente, en 1915, crea El Espectador, ambos con talante nacionalista. A mediados de la década, Isidro Valmenta, destacado dirigente de la masonería local, funda La Opinión.

En Iloilo, a la prensa aparecida en el inicio del siglo, como los diarios El Tiempo, federalista, dirigido ahora por José B. Magalona, y Nuevo Heraldo (1904-1916), conservador independiente, que dirige en sus últimos tiempos Fravio Zaragoza Cano (1892-1965), se van uniendo otros títulos. Un dirigente nacionalista que morirá muy joven, Nicolás Jalandoni (1882-1911), crea en julio de 1907 El Adalid -«diario bilingüe defensor de los ideales del pueblo filipino»-, lo dirigirán Federico Ortiz y luego Engracio Padilla, notario. Se mantiene hasta 1927, no sin dificultades, incluidas las derivadas de frecuentes sanciones, como las de 1913 a tres redactores (1.000 pesos cada uno), difunde unos modestos 700 ejemplares. Posteriores, datan ambos de 1918, son El Pueblo y El Centinela, diarios. En 1913 se edita por poco tiempo la revista cultural Biblioteca llocana.

Zamboanga, en Mindanao, ciudad menor que Cebú o lloilo, no alcanza aún a crear diarios, pero si numerosos y estimables bisemanarios como La Unión, en 1913, La Voz de Mindanao, en 1914, El Pueblo -«catecismo democrático»-, en 1915, La Voz del pueblo, que dirigirá Santiago Mendoza y asoma también en 1915, y a final de la década El Eco de Dava y, en 1919, El Fénix, que dirige José Erquiaga. En San Fernando, región de Pampanga, veremos aparecer semanarios como El Imparcial en 1907, que será sucedido en la década siguiente por El Paladín, en ambos será figura decisiva el escritor en lengua española Zoilo Hilario (San Fernando, 1891-1963). En Tuguegarao Adrián Guzmán crea en 1914 el semanario La Verdad, en español, con sección en ibanag. Alcanza el cuarto de siglo de existencia, y en sus últimos años incluye una sección en inglés. En Lingayen, región de Pangasinan, veremos surgir con edición en español y pangasiano, primero Palaris, en 1914, semanal, y luego, en 1917, Heraldo pangasinan, también semanario.

Los años diez serán también los de expansión de la prensa católica, en gran parte en español, impulsada por una Iglesia que ha superado los difíciles años iniciales de siglo, de fuerte anticlericalismo, como hemos resaltado, por la vinculación del clero con el régimen colonial español. Ahora, junto al diario Libertas veremos numerosos periódicos menores, bastante estables por lo general, en Cebú, por ejemplo, el futuro arzobispo José María Cuenco (Cebú, 1885-1972) impulsa en 1915 el semanario El Boletín católico, que se mantendrá hasta los días de la guerra. En Calvayog el obispado lanza en 1911 Eco de Samar y Leyte, semanal, que alcanza las tres décadas de vida. En 1918 la Federación católica de Filipinas imprime en la capital La Verdad, mensual, pero no pasa de los números iniciales. Las Congregaciones Marianas publican el mensual 
Hoja azul. El título principal será Cultura social, revista mensual que comienza en 1913, impulsada por el arzobispado de Manila, llamada a relativa larga duración -cesa a finales de 1941, con la guerra-, de un contenido muy conservador, del que es muestra este editorial del número 113, de mayo de 1922:

¿Por qué, si somos nosotros, católicos, hemos de buscar el aprecio, el favor y la amistad de nuestros enemigos los herejes o sectarios? ¿Por qué, si sabemos que su culto es falso e injurioso a nuestro Dios, hemos nosotros de asistir a sus funciones, bautizos, matrimonios o entierros? ¿Por qué hemos de secundar sus obras, y comunicar con ellos, más o menos directamente en asuntos de religión? ¿No creemos que los herejes y los sectarios son enemigos de nuestro Dios, que es nuestro verdadero Padre? Pues, ¿por qué los hemos de tratar como si fueran de nuestra propia familia? Si San Pablo en su segunda carta, capítulo V, exhorta a los fieles de Corinto a que no se mezclen, ni en los banquetes, con los deshonestos, con los maldicientes, ¿cuánto más habrá que huir de los herejes y sectarios, por ser el pecado de estos mucho más grave que el de los primeros?

En el número de noviembre del mismo año, Cultura Social ofrece una relación de prensa católica filipina. Son 17 títulos, de ellos siete exclusivamente en castellano, incluido el diario La Defensa, uno en inglés, otro en tagalo, en tanto ocho se redactan en varios idiomas, casi siempre uno de ellos es el español.

La prensa especializada, salvo la religiosa, se concentra en Manila. Conforme avanza la década esa prensa tiende a expresarse preferentemente en inglés. No dejan de aparecer nuevos títulos en lengua española, pero en número inferior al de la década precedente. Surgen periódicos satíricos, como El Antípoda, quincenal de 1919, y El Antifraile, por las mismas fechas, pero es un género que parece agotarse. Feria de Novedades es una revista comercial semanal que asoma en 1915, animada por José A. del Barrio, pero no consigue consolidarse. A partir de 1913 se imprime El día filipino, a modo de anuario ilustrado, que tampoco arraiga. En 1914-1915 Teodoro M. Kalaw dirige el boletín mensual masónico Hojas sueltas. En 1918 otro breve intento de revista ilustrada, la Revista Popular de Filipinas. El colegio católico San Beda, de los benedictinos, toda una institución en Manila, crea en 1916 la revista mensual Ecos, que seguirá hasta la guerra, pero en los años treinta es ya una revista bilingüe españolinglés.

Se mantienen publicaciones como el Boletín oficial de la Cámara de Comercio española en Filipinas, en nueva época desde 1916, mensual; alcanza a 1941. En 1918 Luis Sors vende Excelsior, decenario, al empresario filipino Adolfo García, aunque continúa al frente de la publicación, que se convierte en un buen exponente del notable momento que alcanza entonces la literatura filipina en lengua española. Sigue la Revista filipina de Medicina y Farmacia, mensual, pero se echan en falta, y es significativo, revistas educativas e incluso jurídicas. 
Los años diez son también una etapa de florecimiento de las publicaciones bilingües en inglés y español, donde el español ocupa en principio una posición destacada. Y por lo general con notable duración. En 1904 surgía en Manila el mensual Justicia, con predominio del español; en 1908 se crea Philippines Free Press, un semanario de amplia circulación, llamado a muy larga vida -sigue en publicación, desde hace años como decano de la prensa filipina-, bilingüe es asimismo The Philippine Review/Revista Filipina, que tendrá como director-propietario a Gregorio Nieva, que la mantiene de 1916 a 1921, como revista de alta paginación, y cuidado contenido fotográfico donde publican textos muchos de los mejores escritores en español de la época y destacados políticos: Jesús Balmori, Epifanio de los Santos, Francisco Varona, Joaquín Pellicena, Sergio Osmeña...

\section{La decadencia: 1920-1941}

Tras los cambios de 1918-1919, con la irrupción de El Debate y La Defensa, apenas se crean diarios en español en Manila, aunque si aparecerán algunos en ciudades como Iloilo o Cebú. En 1925 comienza en la capital La Opinión, que al año siguiente -el 15 de abril de 1926- se fusiona con El Comercio, veterano y en decadencia, para quien la muerte de su director y propietario, José Ageo de Loyzaga en ese año resulta decisiva. La cabecera fusionada se mantendrá hasta el 30 de septiembre de 1938. En sus primeros años lo dirige el escritor en español y tagalo Rosauro Almario (Manila, 18861933). Pero antes de esa fusión han desaparecido La Nación en 1923 -el nacionalismo filipino tiende ya como hemos visto a expresarse en inglés, además de los idiomas locales- y El Ideal, que lo hace en 1922, fecha en que también ha cesado La Democracia. Comparativamente, los datos no son tan negativos. Filipinas ofrece en la tercera década del siglo una veintena de diarios, de ellos diez son redactados exclusivamente en español, cinco en Manila y cinco, dato llamativo, en Iloilo, hay tres diarios en inglés, dos en tagalo y otros dos en chino -todos en Manila-, y dos diarios bilingües en Cebú, uno de ellos - La Revolución- en español y cebuano. En 1920 o 1925 lanzar un nuevo diario es empresa mucho más compleja que en 1900 o 1905. Comienzan a configurarse grupos empresariales que editan periódicos en varios idiomas.

Pero si en el sector de diarios en español las novedades comienzan a ser escasas y su número tiende a reducirse, algunos tipos de prensa especializada siguen brotando. En junio de 1923 comienza el Boletín eclesiástico de Filipinas, que había conocido una primera etapa en el periodo colonial. Impulsado por el arzobispado, se mantendrá en edición mensual hasta diciembre de 1941, cuando la II Guerra Mundial Ilega a Filipinas, reaparece en 1946 y se mantiene con edición en español hasta 1960, continúa luego 
en inglés. Su primer director, hasta 1928 será Francisco Cubeñas, rector del seminario, le continuará hasta 1933 el P. Alberto Santa María. En el mismo año, de visible replanteamiento de su política de prensa por parte de la iglesia católica filipina y con importante papel de la Universidad Santo Tomás, surgen, asimismo en Manila, el Boletín de la iglesia de San Ignacio y Hojas del catecismo, dos publicaciones mensuales, la segunda de más larga vida. En Zamboanga se crea Hojas católicas, quincenal. En 1929 comienza a editarse en Manila el Boletín de los Caballeros de Colón, que solo se mantiene hasta 1931.

Título relevante es Trabajo, un mensual que crea en 1921 Joaquín Balmori, hermano del escritor Jesús Balmori. Joaquín ha ido uno de los impulsores en 1917 de la Federación del Trabajo de Filipinas y en ese 1921 impulsa su órgano oficial, Trabajo, un modesto pero meritorio periódico en español y tagalo que se va mantener hasta la guerra, en sus últimos años como quincenal. En 1923 se edita, pero por poco tiempo, El progreso económico de Filipinas, mensual, y en 1924 se crea, con poca vida asimismo, Estudio, semanal. En 1925 aparecen dos modestos periódicos portuarios mensuales, en Manila el Heraldo Marítimo, y en Cebú el Boletín Marítimo. En septiembre de 1927 nuevo intento de revista femenina, La Mujer, muy breve. Brotan también revistas de carnaval, por lo general episódicas, como Carnaval y Confetti (1921), ésta en español y tagalo.

El panorama fuera de Manila es diferente; aunque el inglés avanza en la prensa diaria, veremos editase un buen número de diarios bilingües, en el que normalmente el español es uno de los dos idiomas y el otro la lengua de la región. El proceso más relevante es el que vive la prensa en lloilo, que desde los años diez se convierte en eje de la industria azucarera y vive un buen momento económico, que se traduce en una buena coyuntura para su prensa, todavía redactada de forma claramente mayoritaria en español, de forma que durante la década de los veinte se editarán en la ciudad cinco diarios en lengua española a un tiempo. El Adalid, el título veterano, El Centinela, de 1918, El Pueblo, del mismo año, La Tribuna, de 1923, y Prensa Libre, de 1925, que ha sido precedido por La Prensa. Estos dos últimos son diarios creados por José María Nava (1891-¿ं?), personaje polifacético, escritor y cantante, pero sobre todo destacado líder obrero y artífice de la creación de la Federación Obrera de Filipinas, en tanto los demás, con matices, representan los intereses de los empresarios azucareros.

También surgen los periódicos menores redactados exclusivamente en español: Ideales, que comienza en 1920 en Daguyan, por ejemplo, un quincenal que se edita durante una década; o El Imparcial, bisemanario de Zamboanga, que dirige Agustín L. Álvarez. Lo usual es ya el bilingüismo: en Vigan asoma en 1923 El Mensajero, en español e ilocano; en Silay lo hacen Civismo, trisemanario en castellano y bisayano en 1924 y al año siguiente El Nacional, semanario en los mismos idiomas. Vox Populi, se 
edita en Lucena desde 1925 como semanario bilingüe, pero en este caso español e inglés.

En 1920 se crea el premio Zóbel, hoy el galardón literario más antiguo de Filipinas, para premiar la creación en lengua española. En los años siguientes lo obtendrán buen número de escritores-periodistas, como Manuel Bernabé, Enrique K. Laygo, Manuel Ravago, Jesús Balmori, Flavio Zaragoza o Pedro Aunario.

Cuadro no 2.- La prensa en español de Filipinas en 1927

\begin{tabular}{|c|c|c|c|c|c|}
\hline Título & Ciudad & $\begin{array}{l}\text { Frecuencia } \\
\text { de } \\
\text { aparición }\end{array}$ & $\begin{array}{l}\text { Funda } \\
\text { ción }\end{array}$ & Idiomas & Rasgos. Difusión \\
\hline El Adalid & Iloilo & Diario & 1907 & Español & $\begin{array}{l}\text { Información } \\
\text { general }\end{array}$ \\
\hline Ang katarungan & Cagayan & Semanal & 1917 & $\begin{array}{l}\text { Español y } \\
\text { bisayano }\end{array}$ & $\begin{array}{l}\text { Información } \\
\text { general }\end{array}$ \\
\hline The Bicol news & Naga & Bisemanal & 1926 & $\begin{array}{l}\text { Inglés, } \\
\text { español y } \\
\text { bicolano }\end{array}$ & $\begin{array}{l}\text { Información } \\
\text { general }\end{array}$ \\
\hline Boletín católico & Cebú & Semanal & 1915 & $\begin{array}{l}\text { Español, } \\
\text { inglés y } \\
\text { bisayano }\end{array}$ & Católico \\
\hline $\begin{array}{l}\text { Boletín de la } \\
\text { iglesia de San } \\
\text { Ignacio }\end{array}$ & Manila & Mensual & 1923 & Español & Católico \\
\hline $\begin{array}{l}\text { Boletín } \\
\text { eclesiástico de } \\
\text { Filipinas }\end{array}$ & Manila & Mensual & 1923 & Español & Católico \\
\hline $\begin{array}{l}\text { Boletín } \\
\text { marítimo }\end{array}$ & Cebú & Mensual & 1925 & Español & $\begin{array}{l}\text { Información } \\
\text { portuaria }\end{array}$ \\
\hline $\begin{array}{l}\text { Boletín oficial de } \\
\text { la Cámara de } \\
\text { Comercio } \\
\text { española en } \\
\text { Filipinas }\end{array}$ & Manila & Mensual & 1916 & Español & Comercial \\
\hline Cable Tow & Manila & Mensual & 1923 & $\begin{array}{l}\text { Inglés y } \\
\text { español }\end{array}$ & Masónico \\
\hline Centinela, El & Iloilo & Diario & 1918 & Español & $\begin{array}{l}\text { Información } \\
\text { general }\end{array}$ \\
\hline $\begin{array}{l}\text { China Light } \\
\text { review }\end{array}$ & Manila & Mensual & 1926 & $\begin{array}{l}\text { Inglés, } \\
\text { español y } \\
\text { chino }\end{array}$ & $\begin{array}{l}\text { Comunidad } \\
\text { china }\end{array}$ \\
\hline
\end{tabular}




\begin{tabular}{|c|c|c|c|c|c|}
\hline Civismo & Silay & Trisemanal & 1924 & $\begin{array}{l}\text { Español y } \\
\text { bisayano }\end{array}$ & $\begin{array}{l}\text { Información } \\
\text { general }\end{array}$ \\
\hline Cultura social & Manila & Mensual & 1913 & Español & $\begin{array}{l}\text { Órgano del } \\
\text { Ateneo de } \\
\text { Manila }\end{array}$ \\
\hline El Debate & Manila & Diario & 1913 & Español & Independiente \\
\hline La Defensa & Manila & Diario & 1919 & Español & Católico \\
\hline $\begin{array}{l}\text { Diario de } \\
\text { sesiones de la } \\
\text { legislatura } \\
\text { filipina }\end{array}$ & Manila & Diario & 1926 & $\begin{array}{l}\text { Español e } \\
\text { inglés }\end{array}$ & $\begin{array}{l}\text { Parlamento } \\
\text { filipino }\end{array}$ \\
\hline$E \cos$ & Manila & Mensual & 1916 & Español & $\begin{array}{l}\text { Escolar (Colegio } \\
\text { San Beda) }\end{array}$ \\
\hline $\begin{array}{l}\text { Eco de Samary } \\
\text { Leyte }\end{array}$ & Calbayog & Semanal & 1911 & $\begin{array}{l}\text { Español y } \\
\text { bisayano }\end{array}$ & $\begin{array}{l}\text { Católico } \\
\text { (obispado) }\end{array}$ \\
\hline Estudiantina & Cebú & Mensual & 1925 & $\begin{array}{l}\text { Español e } \\
\text { inglés }\end{array}$ & $\begin{array}{l}\text { Escolar (Colegio } \\
\text { San Carlos) }\end{array}$ \\
\hline Excelsior & Manila & Decenal & 1909 & Español & $\begin{array}{l}\text { Literatura y } \\
\text { amenidades }\end{array}$ \\
\hline $\begin{array}{l}\text { Far Eastern free } \\
\text { mason }\end{array}$ & Manila & Mensual & 1916 & $\begin{array}{l}\text { Inglés y } \\
\text { español }\end{array}$ & $\begin{array}{l}\text { Masónico rito } \\
\text { escocés }\end{array}$ \\
\hline El Fénix & Zamboanga & Bisemanal & 1919 & Español & $\begin{array}{l}\text { Información } \\
\text { general }\end{array}$ \\
\hline El Filipino & Manila & Quincenal & 1923 & $\begin{array}{l}\text { Inglés, } \\
\text { español e } \\
\text { ilocano }\end{array}$ & $\begin{array}{l}\text { Información } \\
\text { general }\end{array}$ \\
\hline Heraldo Bicol & Legazpi & Bisemanal & 1914 & $\begin{array}{l}\text { Inglés, } \\
\text { español y } \\
\text { bicolano }\end{array}$ & $\begin{array}{l}\text { Información } \\
\text { general }\end{array}$ \\
\hline $\begin{array}{l}\text { Heraldo } \\
\text { marítimo }\end{array}$ & Manila & Mensual & 1924 & Español & $\begin{array}{l}\text { Información } \\
\text { portuaria }\end{array}$ \\
\hline Hojas católicas & Zamboanga & Quincenal & 1923 & Español & Católico \\
\hline $\begin{array}{l}\text { Hojas de } \\
\text { catecismo }\end{array}$ & Manila & Semanal & 1923 & Español & Católico \\
\hline Ideales & Dagupan & Quincenal & 1920 & Español & $\begin{array}{l}\text { Información } \\
\text { general }\end{array}$ \\
\hline El Imparcial & Zamboanga & Bisemanal & 1924 & Español & $\begin{array}{l}\text { Información } \\
\text { general }\end{array}$ \\
\hline The & Manila & Semanal & 1915 & Inglés y & Información \\
\hline
\end{tabular}




\begin{tabular}{|c|c|c|c|c|c|}
\hline Independent & & & & español & general \\
\hline Isagani & Manila & Semanal & 1925 & Español & $\begin{array}{l}\text { Información } \\
\text { general }\end{array}$ \\
\hline $\begin{array}{l}\text { Kusug sa } \\
\text { Katarungan }\end{array}$ & Dumaquete & Semanal & 1926 & $\begin{array}{l}\text { Español, } \\
\text { inglés y } \\
\text { bisayano }\end{array}$ & $\begin{array}{l}\text { Información } \\
\text { general }\end{array}$ \\
\hline La Lucha & Manila & Semanal & 1909 & $\begin{array}{l}\text { Español e } \\
\text { ilocano }\end{array}$ & $\begin{array}{l}\text { Información } \\
\text { general }\end{array}$ \\
\hline El Mensajero & Vigan & Semanal & 1923 & $\begin{array}{l}\text { Español e } \\
\text { ilocano }\end{array}$ & $\begin{array}{l}\text { Información } \\
\text { general }\end{array}$ \\
\hline El Mercantil & Manila & Diario & 1902 & Español & $\begin{array}{l}\text { Información } \\
\text { general }\end{array}$ \\
\hline $\begin{array}{l}\text { Monthly Bulletin } \\
\text { of the Philippine } \\
\text { Health Service }\end{array}$ & Manila & Mensual & 1925 & $\begin{array}{l}\text { Inglés y } \\
\text { español }\end{array}$ & Salud \\
\hline El Nacional & Silay & Semanal & 1925 & $\begin{array}{l}\text { Español y } \\
\text { bisayano }\end{array}$ & $\begin{array}{l}\text { Información } \\
\text { general }\end{array}$ \\
\hline El Obrero & Tacloban & Semanal & 1924 & $\begin{array}{l}\text { Español, } \\
\text { inglés y } \\
\text { bisayano }\end{array}$ & $\begin{array}{l}\text { Información } \\
\text { general }\end{array}$ \\
\hline Official Gazette & Manila & Trisemanal & 1905 & $\begin{array}{l}\text { Inglés y } \\
\text { español }\end{array}$ & $\begin{array}{l}\text { Información } \\
\text { oficial }\end{array}$ \\
\hline $\begin{array}{l}\text { La Opinión-El } \\
\text { Comercio }\end{array}$ & Manila & Diario & 1926 & Español & $\begin{array}{l}\text { Información } \\
\text { general }\end{array}$ \\
\hline $\begin{array}{l}\text { Philippine } \\
\text { Agricultural } \\
\text { Review }\end{array}$ & Manila & Trimestral & 1908 & $\begin{array}{l}\text { Inglés y } \\
\text { español }\end{array}$ & Agricultura \\
\hline $\begin{array}{l}\text { Philippines Free } \\
\text { Press }\end{array}$ & Manila & Semanal & 1908 & $\begin{array}{l}\text { Inglés y } \\
\text { español }\end{array}$ & Independiente \\
\hline Pinoy & Capiz & Semanal & 1926 & $\begin{array}{l}\text { Inglés, } \\
\text { español y } \\
\text { bisayano }\end{array}$ & $\begin{array}{l}\text { Información } \\
\text { general }\end{array}$ \\
\hline The Plain Dealer & Manila & Semanal & 1926 & $\begin{array}{l}\text { Inglés y } \\
\text { español }\end{array}$ & $\begin{array}{l}\text { Información } \\
\text { general }\end{array}$ \\
\hline El Precursor & Cebú & Bisemanal & 1908 & $\begin{array}{l}\text { Español y } \\
\text { bisayano }\end{array}$ & $\begin{array}{l}\text { Información } \\
\text { general }\end{array}$ \\
\hline Prensa libre & Iloilo & Diario & 1925 & Español & $\begin{array}{l}\text { Información } \\
\text { general }\end{array}$ \\
\hline El Pueblo & Iloilo & Diario & 1918 & Español & $\begin{array}{l}\text { Información } \\
\text { general }\end{array}$ \\
\hline
\end{tabular}




\begin{tabular}{|c|c|c|c|c|c|}
\hline $\begin{array}{l}\text { Revista de la } \\
\text { Cámara de } \\
\text { Comercio de las } \\
\text { islas Filipinas }\end{array}$ & Manila & Mensual & 1915 & Español & Comercio \\
\hline $\begin{array}{l}\text { Revista filipina } \\
\text { de Medicina y } \\
\text { Farmacia }\end{array}$ & Manila & Mensual & 1910 & Español & Medicina \\
\hline La Revolución & Cebú & Diario & 1915 & $\begin{array}{l}\text { Español y } \\
\text { bisayano }\end{array}$ & $\begin{array}{l}\text { Información } \\
\text { general }\end{array}$ \\
\hline Sinceridad & Tuguegarao & Semanal & 1926 & $\begin{array}{l}\text { Español, } \\
\text { inglés e } \\
\text { ibanago }\end{array}$ & $\begin{array}{l}\text { Información } \\
\text { general }\end{array}$ \\
\hline $\begin{array}{l}\text { Sugar Central } \\
\text { and Planters } \\
\text { News }\end{array}$ & Manila & Mensual & 1920 & $\begin{array}{l}\text { Inglés y } \\
\text { español }\end{array}$ & Economía \\
\hline $\begin{array}{l}\text { Tingog sa } \\
\text { Lungsod }\end{array}$ & Dumaquete & Semanal & 1926 & $\begin{array}{l}\text { Español, } \\
\text { inglés y } \\
\text { visayano }\end{array}$ & $\begin{array}{l}\text { Información } \\
\text { general }\end{array}$ \\
\hline El Trabajo & Manila & Mensual & 1921 & $\begin{array}{l}\text { Español y } \\
\text { tagalo }\end{array}$ & Obrerista \\
\hline La Tribuna & Iloilo & Diario & 1923 & Español & $\begin{array}{l}\text { Información } \\
\text { general }\end{array}$ \\
\hline Unitas & Manila & Mensual & 1922 & Español & $\begin{array}{l}\text { Universidad } \\
\text { Santo Tomás }\end{array}$ \\
\hline La Vanguardia & Manila & Diario & 1910 & Español & $\begin{array}{l}\text { Información } \\
\text { general }\end{array}$ \\
\hline La Verdad & Tuguegarao & Semanal & 1914 & $\begin{array}{l}\text { Español e } \\
\text { ibanago }\end{array}$ & $\begin{array}{l}\text { Información } \\
\text { general }\end{array}$ \\
\hline Vox Populi & Lucena & Semanal & 1925 & $\begin{array}{l}\text { Inglés y } \\
\text { español }\end{array}$ & $\begin{array}{l}\text { Información } \\
\text { general }\end{array}$ \\
\hline $\begin{array}{l}\text { La Voz del } \\
\text { pueblo }\end{array}$ & Zamboanga & Bisemanal & 1915 & Español & $\begin{array}{l}\text { Información } \\
\text { general }\end{array}$ \\
\hline $\begin{array}{l}\text { Woman's } \\
\text { outlook }\end{array}$ & Manila & Mensual & 1922 & $\begin{array}{l}\text { Inglés y } \\
\text { español }\end{array}$ & $\begin{array}{l}\text { Revista } \\
\text { ilustrada }\end{array}$ \\
\hline
\end{tabular}

La década que precede a la entrada de Filipinas en la II Guerra Mundial, los años treinta, representan una etapa muy intensa para el país, que en 1934 se dota de un avanzado régimen de autonomía que debe preceder a la plena independencia, prevista 
para una década después. El español se mantiene como idioma oficial, pero al inicio de los años treinta se estima que es ya el idioma habitual de poco más de 400.000 filipinos -con creciente edad promedio-, cuando el país alcanza los 20 millones de habitantes. Al final de la década, el país superan las 300 publicaciones, de ellas una cuarta parte incluyen informaciones en español; solo 25 se editan ya exclusivamente en castellano, si bien ocho de ellas son diarios.

No se crean nuevos diarios en español en Manila. El principal órgano católico, el diario La Defensa, ha de pasar en 1931 a bisemanal e incluir secciones en inglés. Antes, a finales de 1930, ha cesado El Mercantil, cuando la avanzada edad de Romero Salas que fallece en 1931- le impide dirigirlo, y como empresa muy personal, y bien poco rentable, no sobrevive. El intento promovido por Voz española de fusionar publicaciones menores y lanzar un diario, a fines de 1932, no cuaja. Manila mantiene solo tres diarios en español, dos de ellos La Vanguardia y El Debate, se vinculan a grandes grupos de comunicación para los que el cotidiano en español es secundario. La Opinión-El Comercio se mantiene con dificultad sin ese paraguas y acaba sucumbiendo en 1938. Mediada la década se estima que esa prensa exclusivamente en español, no alcanza los 80.000 ejemplares, muy por bajo de la impresa en inglés, que supera ya el centenar y medio de publicaciones, entre ellas varios diarios de gran difusión, y también por la editada en tagalo. Esos títulos, incluidos los ocho diarios de información general, es un número apreciable, pero se trata visiblemente de órganos de reducida audiencia. El grupo TVT, el de la familia Roces, mantiene, junto a publicaciones menores, pero algunas -como el semanario Liwayway- de notable tirada, tres diarios, The Tribune, en inglés, Taliba, en tagalo, y La Vanguardia en español. Este diario, ahora de gran formato, ocho columnas, ofrece un suplemento semanal, "Sabatino de La Vanguardia». El otro gran grupo es DMHM, propiedad del naviero Vicente Madrigal y con otro destacado empresario, Andrés Soriano, entre los principales accionistas, con The Philippine Herald, en inglés, Mabuhay, en tagalo, y El Debate, en español. En inglés y español se redactan el Diario de Sesiones de la Asamblea filipina y la Official Gazette, trisemanal, ésta desde 1905. La Vanguardia y EI Debate, difunden en conjunto en 1940 los 32.000 ejemplares.

Fuera de Manila, si bien se mantienen, algo mejor, media docena de diarios, apenas se crean títulos nuevos. En Cebú, por ejemplo, solo comienza en los años veinte un nuevo periódico en español, el semanario El Demócrata, de 1928, impulsado por el líder político Nicolás Rafols (Toledo, Cebú, 1894-Manila, 1947); incluso la iglesia católica se inclina por órganos en lengua local, cebuano, como el semanario Lungsuranon (1934), aunque se mantiene El Boletín católico, en español. No obstante, en 1940 aparecerá, promovido por la familia Escaño, notable grupo empresarial local, un nuevo diario en español, La Nación, que los acontecimientos de 1941, con la invasión japonesa, convierten en efímero. En los mismos días cesan también, obligados por las circunstancias, La Revolución, diario, y El Precursor, bilingüe, en sus últimos años 
bisemanario. En 1936-1937 se edita también en Cebú un modesto quincenal en español, Patria.

Mejor es la situación en lloilo, donde se editan en estos años cuatro diarios en español, de pequeña tirada todos: El Centinela, que dirige Luis Guzmán Rivas, otro escritorperiodista que en 1940 obtendrá el premio Zóbel, La Tribuna, dirigido por Patricio Zaldariaga (1883-1954), El Tiempo, fundado en 1929, y Prensa Libre, el único de ellos con orientación de izquierdas. En 1936 se crea la revista mensual Chismes.

Otra media docena ciudades ofrecen prensa de información general en español, pero ya no como único idioma, serán Zamboanga, Bacolod, Tuguegarao, Legazpi, Ilagan y Calbayog. Destaca la prensa de la primera, con el trisemanario La Antorcha y los bisemanarios El Criterio y El Informador que, surgidos a principio de la década de los treinta, llegarán hasta los días de la guerra. Se editan en español, «dialecto» chabacano- e inglés. En Ilagan se edita desde 1935 La Atalaya, en Bacolod se crea en el mismo año La Linterna, semanario de talante progresista, dirigido por Alberto Vásques. Al mismo tiempo continúan desde los años diez La Verdad, en Tuguegarao; Heraldo de Bicol, en Legazpi, y Eco de Samar y Leyte en Calbayog.

En 1937 el tagalo pasa a ser considerado lengua oficial, y aunque el español se mantiene asimismo, formalmente, como lengua estatal, su carácter subalterno es patente. El inglés domina la escuela y el ámbito público. En Manila y algunas ciudades importantes se mantienen colegios religiosos, con enseñanza en español, pero por lo general elitistas. Varios editan revistas, como El Letranense, órgano del colegio San Juan de Letrán de Manila, dirigido por dominicos. Su papel como lengua familiar es ya muy reducido. Pese a ello, se constata que en los años treinta y hasta la guerra, no dejan de aparecer pequeños periódicos en español, aunque se evidencia que van dirigidos mucho más a la propia colonia española que al público filipino en general. Al inicio de la década, por ejemplo, asoman en Manila los semanarios Voz española y Nuestra España; aquel es un semanario de 1931-1932, que funda Alberto Carlos, de un feroz conservadurismo, que le llevara a defender al dictador Primo de Rivera e incluir colaboraciones de los escritores o políticos españoles más conservadores, de Ramiro de Maeztu al doctor Albiñana. Simpatizante de la República, pero equilibrado, es Nuestra España, que dirige Carlos de Oteyza y tiene un final significativo: los núcleos antirrepublicanos de la colonia española en Manila, económicamente potentes, planifican su desaparición: adquieren el periódico, que atraviesa dificultades, pagan atrasos y lo cierran al poco. En ambos casos, sus informaciones, con amplio contenido sobre cuanto ocurre en la península ibérica, van claramente destinadas a la comunidad española en las islas. No es el caso, pero constituye una excepción, de Unión, un semanario que comienza en 1932 dirigido por el veterano líder independentista Vicente Sotto, como órgano del partido que encabeza, Unión Cívica. Será el principal defensor de la Republica española en Filipinas. En 1936 añade una sección en inglés. 
En similar línea, Estado Libre, semanario que comienza en 1936. Cuando estalla en 1936 la guerra en España, esa prensa en español filipina defenderá en su mayoría al bando de los sublevados, que incluso crea una prensa afín, como los periódicos y boletines Yugo, impulsado por simpatizantes de Falange Española y dirigido por Antonio Ferrer Gutiérrez, Flechas, Arriba España y Pro Cervantes -éste más orientado a la defensa del idioma-, mensual dirigido por Enrique de Maristela, en tanto la república contará con las simpatías de Democracia española, decenal, que impulsa en 1937 el español Pío Brun Cuevas y llega al fatídico 1941 (Rodao, 2012: 468- 491). Claramente inclinada al bando franquista está asimismo Excelsior, la principal revista ilustrada, que en 1934 alcanzaba los mil números editados, pero que pasa de decenal a quincenal y en 1937 a mensual, manteniendo con dificultades los 2.500 ejemplares de venta promedio.

Aunque no falta algún nuevo periódico satírico -como Kikirikí, mediada la década- y desde luego muchas nuevas publicaciones católicas -Todos misioneros, Juan de la Cruz, Apostolado de la Oración, en Manila, El Misionero, en Baguío...- la prensa en español atraviesa crecientes dificultades ante la paulatina reducción de su público potencial. En ese contexto, la invasión japonesa, iniciada en diciembre de 1941 en el transcurso de la II Guerra Mundial, inicia un profundo proceso de cambio en el que la prensa en español será precisamente la gran perdedora, ausente en la prensa de la guerrilla, y con el estigma de la vinculación de España con los países del Eje, aunque al final del conflicto, en abril de 1945, de forma muy oportunista, España declare la guerra a Japón.

\section{Conclusiones}

El final de la breve guerra entre España y EE UU, que supone para la primera la pérdida de las islas, inicia una nueva etapa en la evolución de la prensa en Filipinas, si en principio los órganos redactados en español son mayoritarios y abarcan muy distintos tipos de prensa, incluida la más nacionalista y hasta en algunos casos la pronorteamericana, y desde luego la católica, luego la imposición paulatina del inglés como lengua escolar y económica irá relegando al español y a su prensa, a partir sobre todo de que -mediados los años veinte- pasen a dominar en la sociedad filipina las primeras generaciones educadas en lengua inglesa.

Entre 1898 y 1899 hay una clara continuidad - no hay ningún tipo de represión contra los españoles, si contra los independentistas filipinos- en las personas que realizan los periódicos filipinos, pero no en las cabeceras, donde la rupturas es casi total. 
No se detectan esfuerzos ni estrategias desde España para ayudar al mantenimiento de esa prensa en español $-y$ obviamente tampoco desde las repúblicas latinoamericanas-, fuera de alguna declaración platónica. Casi se desconoce su propias importancia, como muestra algún viajero español por el archipiélago, Vicente Blasco Ibáñez es un ejemplo. Si se evidencia en el nacionalismo filipino $-y$ el movimiento obrero- que eligen claramente en principio el idioma español como instrumento vehicular para llegar a un pueblo caracterizado precisamente por la dispersión lingüística -Filipinas mantiene por entonces en torno a las 175 lenguas vivas-; desde los años veinte el nacionalismo tiende a expresarse en inglés, en tanto potencia las lenguas locales, sobre todo el tagalo.

Paulatinamente la prensa redactada en lengua española, y especialmente en Manila, tenderá a ser órgano de la colonia española y en buena medida de la iglesia católica más que expresión del pueblo filipino.

No obstante, esa decadencia no debe ocultar que la prensa en español pasa a ser también en estos años el reflejo de un sugestivo proceso de despegue de la literatura filipina, precisamente en lengua española, o que durante varias décadas los sectores más avanzados de la opinión pública filipina prefieran el español al inglés y, en suma, que en conjunto sean varios cientos de títulos en español los aparecidos desde 1899 hasta que la invasión japonesa de la islas a finales de 1941 rompa de nuevo el panorama, en este caso en detrimento, ahora decisivo, de la prensa en español.

\section{Fuentes}

\section{Bibliográficas}

ARTIGAS CUERVA, Manuel (1909), Los periódicos filipinos: la más completa bibliografía publicada hasta la fecha acerca de los papeles públicos filipinos, Biblioteca Nacional Filipina, Manila, 224 pp. [Disponible, incompleto, en http://hdl.handle.net/2027/miun.arb8044.0001.001]

CAILLES UNSON, Ben (19699, "La literatura hispanofilipina», en Archivum, tomo 19, pp. 275-291,

CANO, Gloria (2011), "Filipino Press between Two Empires: El Renacimiento», en Southeast Asian Studies, Vol. 49, No. 3, pp. 395-430.

COLET VALLADOLID, Alice (2006), «Featuring-- the Philippine press, 1637-2005», Pasig, Manila, $122 \mathrm{pp}$. 
LENT, John A. (1970), "Guerrilla press of the Philippines, 1941-1945» en Asian Studies, volumen $8-2$, pp. 260-174

PALMA, Rafael (1914), Voces de Aliento. Colección de artículos literarios, Imprenta Cultura Filipina, Manila, 217 pp. [Disponible en www.cervantesvirtual.com]

REYES ENCANTO, Georgina (2004), Constructing the Filipina: a history of women's magazines, 1891-2002, University of the Philippines Press, Quezon City, 121 pp.

RODAO, Florentino (2011), «De colonizadores a residentes. Los españoles ante la transición imperial en Filipinas», en Elizalde, María Dolores, y Delgado, Josep María, editores, Filipinas, un país entre dos imperios, UAB, Bellaterra, pp. 251297.

RODAO, Florentino (2012), «El español durante la guerra civil: las revistas ideologizadas», en Donoso Jiménez, Isaac, editor, Historia cultural de la lengua española en Filipinas. Ayer y hoy, Verbum editorial, Madrid, pp. 459-510.

ROPERO, Godofredo (2008), "Cebu media history: evolving through 100 years 19052005», en Philippine Conmunication Centrum, Manila. [Disponible en ww2.aijc.com.ph/OCCF/mediamuseum/timeline/timeline-cebu.htm]

ROSARIO-BRAID, Florangel, y Tuazón, Ramon R. (1999), "Communication Media in the Philippines: 1521-1986»,en Philippine Studies vol. 47, no. 3, pp. 291-318.

SORIANO, D. H. (1987), The Roces family: publishers, with as History of the Philippine Press, Islas Filipinas Pub., Manila, 146 pp.

TAYLOR, Carson (1927), History of the Philippine Press, s/e, Manila, 1927, 62 pp.

\section{Electrónicas}

www.archive.org [colecciones de revistas como Cultura Social o Revista Filipina]

www.cervantesvirtual.com [textos sobre Filipinas]

www.hemerotecadigital.bne.es [colecciones de periódicos como La redención del obrero o Voz española]

Philippine Communication Centrum: http://aijc.com.ph

\section{Repertorios y catálogos}

American newspaper annual and directory, Ayer and son's, Filadelfia, 1903/1922.

Rizal Library/Ateneo de Manila: http://rizal.lib.admu.edu.ph 